\title{
NBSIR 73-169
}

\section{Fire Endurance Test of a Wood Stud Interdwelling Double Wall Construction}

B. C. Son

Center for Building Technology

Institute for Applied Technology

National Bureau of Standards

Washington, D. C. 20234

April 1973

Final Report

\section{Prepared for}

Office of Research and Technology

Department of Housing and Urban Development

Washington, D. C. 20410 

NBSIR 73-169

\section{FIRE ENDURANCE TEST OF A WOOD STUD INTERDWELLING DOUBLE WALL CONSTRUCTION}

B. C. Son

Center for Building Technology Institute for Applied Technology National Bureau of Standards

Washington, D. C. 20234

April 1973

Final Report

Prepared for

Office of Research and Technology

Department of Housing and Urban Development

Washington, D. C. 20410

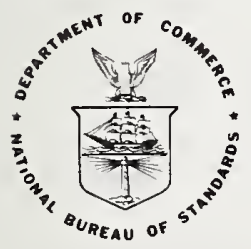

U. S. DEPARTMENT OF COMMERCE, Frederick B. Dent, Secretary

NATIONAL BUREAU OF STANDARDS, Richard W. Roberts, Director 



\author{
B. C. Son \\ Building Fires and Safety Section \\ Center for Building Technology
}

\begin{abstract}
As a part of the evaluation of a housing system proposed under Operation BREAKTHROUGH, a standard fire endurance test was performed on a double wall construction representing a non-load-bearing interdwelling wall for single family attached housing. The test was conducted at the National Bureau of Standards and followed the requirements of ASTM E 119, Fire Tests of Building Construction and Materials.
\end{abstract}

The double wall, which formed an interdwelling separation between two adjacent modules, was made up of two identical parallel walls separated by a $1 / 2$ inch air space. Each wall contained two layers of fire-rated gypsum board attached to wood stud framing on the dwelling room side.

Since the test assembly represented a non-bearing wall, no load was applied during this test.

The failure of the first (fire exposed) wall occurred at $1 \mathrm{hr}$. 17 min. when a joint in the second layer of gypsum board opened to allow passage of flame. 
The second (unexposed) wall failed at $2 \mathrm{hr} .19 \mathrm{~min}$. when the temperature rise at one point on the unexposed surface exceeded the maximum allowable.

Key Words: Fire endurance; fire test; flame-through failure of walls; housing systems; interdwelling wall; Operation BREAKTHROUGH 
Abstract. . . . . . . . . . . . . . . . . . . i

1. Introduction. . . . . . . . . . . . . . . . . . 1

2. Construction. . . . . . . . . . . . . . . . . 1

3. Test Method and Equipment . . . . . . . . . . . . 3

4.0 Test Evaluation. . . . . . . . . . . . . . . . 4

4.1 Test Results . . . . . . . . . . . . . . . 5

5. Discussion. . . . . . . . . . . . . . . . 5

Table I . . . . . . . . . . . . . . . . . . . 7

Appendix I. . . . . . . . . . . . . . . . . . . . 9

SI Conversion Units 



\section{INTRODUCTION}

A standard fire test was conducted at the National Bureau of Standards to measure the fire endurance of a gypsum board and wood stud double wall assembly. The work was sponsored by the Department of Housing and Urban Development under its Operation BREAKTHROUGH program.

The fire exposure followed the requirements of Standard Methods of Fire Tests of Building Construction and Materials, ASTM E 119 $1 /$, as applicable to non-bearing walls, with the exception that the hose stream was omitted.

The double wall, which was required to be a fire barrier between two adjacent modules, was made up of two identical walls parallel to each other. Each consisted of two layers of gypsum board on one side of wood studs. The construction of this specimen was representative of the field construction.

The purpose of this fire test was to study the thermal fire behavior of the assembly when one side of the assembly was subjected to the temperature-time exposure of the standard fire endurance test.

Since the test assembly represented a non-bearing wa11, no load was applied to the assembly during this test.

\section{CONSTRUCTION}

The assembly consisted of two identical $16 \mathrm{ft}$. $8 \mathrm{ft}$.walls parallel to each other. Each wall was made up of two identical $6 \mathrm{ft}$. wide panels

\footnotetext{
1/ Standard Methods of Fire Tests of Building Construction and Materials American Society for Testing and Materials, available at 1916 Race Street, Philadelphia, Pa. 19103.
} 
separated by a $3 \mathrm{ft} .4-1 / 2$ in. wide infill panel. All panels were 8 ft. high. Each panel had two layers of $1 / 2$ in. Type $X$ gypsum board attached to one side of 2 by 3 in. (nominal) wood studs as an interior face. No exterior siding was provided. The 2 by 3 in. (nominal) standard grade wood studs were on 16 inch centers, and framed with a single 2 by 3 in. (nominal) utility grade member at the top and bottom as a plate and sill respectively. The base layer of gypsum board was applied with 1-1/2 in. bright ring-shank nails on 12 in. centers. The face layer of gypsum board was glued to the base layer with construction adhesive and secured with $7 d$ cement coated box nails on 24 in. centers. Joints of base and face layer of gypsum boards were staggered.

The wall panels, with their exterior sides facing, were set $1 / 2$ in. apart. Strips of $1 / 2$ in. Type $X$ gypsum board were placed in the air space between the two walls at the top plate, the sill, the two end studs, and the two panel joints between the infill panel and module walls. The strips of gypsum board were attached to the fire side wall on the wood frame with $1-1 / 2$ in. bright ring-shank nails on $1 / 2$ in. centers. Two types of panel joints were used in order to test the two different joint closures used in field construction. One was regular $1 / 2$ in. thick gypsum board over a 2 by 4 in. (nominal) wood batten, the other, wood archway trim over the batten.

The ends of the panel were built in accordance with actual construction procedures. The details of the joints and end construction are shown in Figure 1 . 


\section{3. 'TES'T' MEI'HOI) AND EQUIPMENT}

The instrumentation consisted of thermocouples and deflection indicators. A total of 15 Chromel-Alumel (type K) thermocouples were used: 4 thermocouples were placed internally in the air space, and 11 thermocouples were placed on the unexposed surface. The unexposed surface thermocouples were covered with 6 × 6 × 0.4 in. thick standard asbestos pads. See Figure 2 for the thermocouple locations. The unexposed surface of the specimen and the thermocouple connections at the beginning of the test are shown in Figure 3. The temperatures measured by the thermocouples were printed out at one minute intervals on a data logger, from which they were transferred to magnetic tape for processing and plotting by computer.

A stationary lateral deflection wire was strung horizontally at the center height of the specimen at 3-1/4 in. from the surface. The distance from the wire to the surface of the specimen was measured at the center and at the two quarter points of the panel periodically during the test with a ruled gage.

The double wall assembly was mounted in a 10 by $16 \mathrm{ft}$ frame of the wall test furnace at the Fire Research Section, National Bureau of Standards. Since the $8 \mathrm{ft}$ height of the specimen was less than the 10 ft high opening of the test frame, a filler piece was placed at the top of the specimen, as shown in Figure 3. The filler piece was made up of $2 \times 12$ (nominal) pine wood and protected on the fire side with two layers of $5 / 8$ in. Type $X$ gypsum board and sprayed fire protective vermiculite plaster on metal lath, and on the unexposed side with a single layer of 


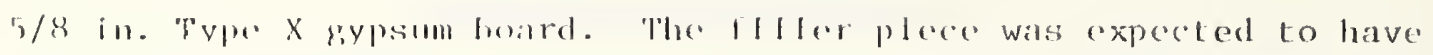

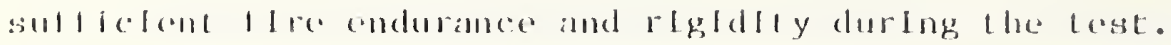

The temperature inside the furnace was measured by 12 chromel-alume 1 thermocouples enclosed in sealed $1 / 2$ in. diameter wrought iron pipes placed 6 in. from the exposed face of the specimen. The furnace temperature was controlled to follow the standard ASTM E 119 temperature-time curve by manual adjustment of the gas flow to the burners. The actual furnace time-temperature curve is shown in Figure 4.

The pressure measurement within the furnace was made with a disk type probe connected to a pressure difference meter. The probe consisted of $1 / 8$ in. inside diameter stainless steel tubing attached to the edges of a 1-1/8 in. diameter flat metal disk having rounded edges and connected to a small hole in the center of the disk. The disk was positioned so that the hole was normal to the upward flow of furnace gases. During the test the furnace neutral pressure point was maintained at one-third height of the specimen above the bottom of the specimen.

\section{TEST EVALUATION}

The fire endurance according to ASTM E 119 of a non-load bearing wall construction is the time required to reach the first occurring of the criteria of failure, which are as follows:

a. Passage of flame or gases through the structure to the unexposed surface hot enough to ignite cotton waste.

b. A temperature rise of $250^{\circ} \mathrm{F}\left(139^{\circ} \mathrm{C}\right)$ average, or $325^{\circ} \mathrm{F}\left(181^{\circ} \mathrm{C}\right)$ at one point above its initial temperature on the unexposed surface. 


\subsection{TEST RESULTS}

A complete $\log$ of test observations is given in Table I. For convenience in reporting the results, the parts of the test specimen will be identified according to their position on the north-south test furnace axis. The average temperature rise of the unexposed surface and the maximum temperature rise during the test are shown in Figure 5. The air space temperatures compared with the furnace temperatures and the unexposed surface temperature are shown in Figure 6.

The failure of the first (fire exposed) wall occurred at $1 \mathrm{hr} 17 \mathrm{~min}$ when flame penetrated through a gypsum joint opening in the base layer of gypsum board of the fire wall in the middle of the north end panel.

The overall fire endurance of the assembly was $2 \mathrm{hr} 19 \mathrm{~min}$ with failure by an excessive temperature rise (over $181^{\circ} \mathrm{C}$ ) at a single point on the unexposed surface of the second (unexposed) wall of the north end pane1.

The lateral deflection along the mid-height of the unexposed surface was barely perceptible during the first hour of the test. After one hour the unexposed surface started slowly to bow out, reaching a maximum of $3 / 4$ in. at the end of the test.

Figure 7 shows the exposed side of the assembly after it was removed from the furnace. All of the first wall has collapsed and most of the wood studs of the second wall have burned away. Note also long cracks on the gypsum boards.

\section{DISCUSSION}

Since the construction was symmetrical, the fire endurance would be expected to be the same if the other side of the assembly had been 
exposed to the fire.

Although failure did not accur at any of the panel joints during the test, the joint behind the wood trim would have failed before the joint behind the gypsum board, if the test had been continued. The batten behind the wood trim began to fall at $57 \mathrm{~min}$, while the one behind the gypsum board was found intact at $1 \mathrm{hr} 31 \mathrm{~min}$. (See the Log of Test Observations in the Table I).

The construction glue used between gypsum boards in this assembly effective1y held the layers of gypsum board together for the duration of the test. However, this might not have been the case if the assembly had been loaded, and was required to withstand the stresses of a bearing structure as well as those resulting from the application of heat.

It is evident that collapse of one wall may immediately endanger the integrity of the facing wall. Also, flame penetration of the first (fire exposed) wall may initiate the spread of fire to adjacent modules through the common air space, unless the gypsum board strips placed as buffers between the modules can act effectively as a fire stop. 


\section{LOC OF TEST OBSERVATIONS}

$\underline{\text { Time }}$

Hr :Min:Sec

\section{Observation}

$0: 00 \quad$ Start of test.

1:00 Wood trim over the archway ignited.

1:30 Paper on the exposed gypsum board burning.

5:00 Wood trim is still burning. Gypsum board on the exposed face is blistering.

16:00 Slight smoke observed at top of the unexposed side of the specimen.

16:30 The $2 \times 3$ module joint protection behind the archway trim is exposed to fire and burning.

20:00 Some flaming noted at the edge of gypsum board covering over the panel joint in the furnace.

25:00 A vertical joint in the gypsum board at the center infill panel has started to open.

30:00 The vertical gypsum board joint in the north panel has opened about $1 / 2$ inch.

34:00 Joint compound on the gypsum joint in the south panel is falling out.

35:00 Flame observed at the gypsum joint opening on the north end panel.

45:00 The wood member for module joint protection behind the trim piece is bowed out about $1 / 2$ inch. Cracking sounds noted from the inside of the wall indicating that some wood members are burning.

57:00 The module joint behind the wood trim is beginning to fall away.

1:13:00 The face layer of gypsum board on the north end panel on the exposed side is bowing out.

1:14:00 Cracking and popping sound from the inside of the pane1 is becoming more severe. 
Time

Hr:Min:Sec

$1: 15: 00$

$1: 17: 00$

$1: 31: 00$

$1: 40: 00$

$1: 50: 00$

$1: 58: 00$

$2: 00: 00$

$2: 15: 00$

$2: 18: 00$

$2: 19: 00$

$2: 22: 00$

\section{Observation}

The joint in the face layer of gypsum board on the exposed side in the north end panel has opened more than 1 inch. The second layer of gypsum board is visible.

First wall failed. The gypsum joint on the second layer of gypsum board on the exposed side in the north panel is opening up.

The gypsum board covering over a panel joint is falling away.

The face layer of the gypsum board near the gypsum joint on the north end panel of the specimen is starting to fall off .

About 40 percent of the face layer of gypsum board on north end panel has fallen off.

The second layer of gypsum board on the exposed panel starting to fall in.

Smoke and steam coming out of the edges of the panel on the unexposed side.

Wood studs on the second wall are burning at the north panel.

Flame through at edge of the panel on north side at furnace frame on the unexposed side, not at a panel joint.

Temperature failure on single point on north end panel.

End of Test.

Gas off. 


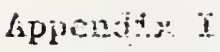

SI Corvarsion Units

In view of preseme acconted pracoice jin this country in this technologica: ayea: common US unjts of measurement have been used throughout this paper. Iil recognition of the position of the Uniled States as a signatory to the General. Conference on Weights and Nersurerents vi:ich gave official status to the netric SI systcm of units in 1960, we assist reacers interested in making use of the colnersat system of $\mathrm{SI}$ units by giving conversicn factors applicable to US units used in this paper.

Length

1 in $=0.0254$ meter

$1 \mathrm{ft}=0.3048$ meiter

Mass

$11 b=0.45 \mathrm{kilogram}$

Stress

1 psf $=47.88$ newton $/$ meter ${ }^{2}$

]. psi $=0.332$ newton/meter ${ }^{2}$

$1 \mathrm{plf}=13.49$ newton/meter

Temperature

Temperature in ${ }^{\circ} \mathrm{F}=9 / 5$ (tenperature in ${ }^{\circ} \mathrm{C}$ ) $+32^{\circ} \mathrm{F}$ 


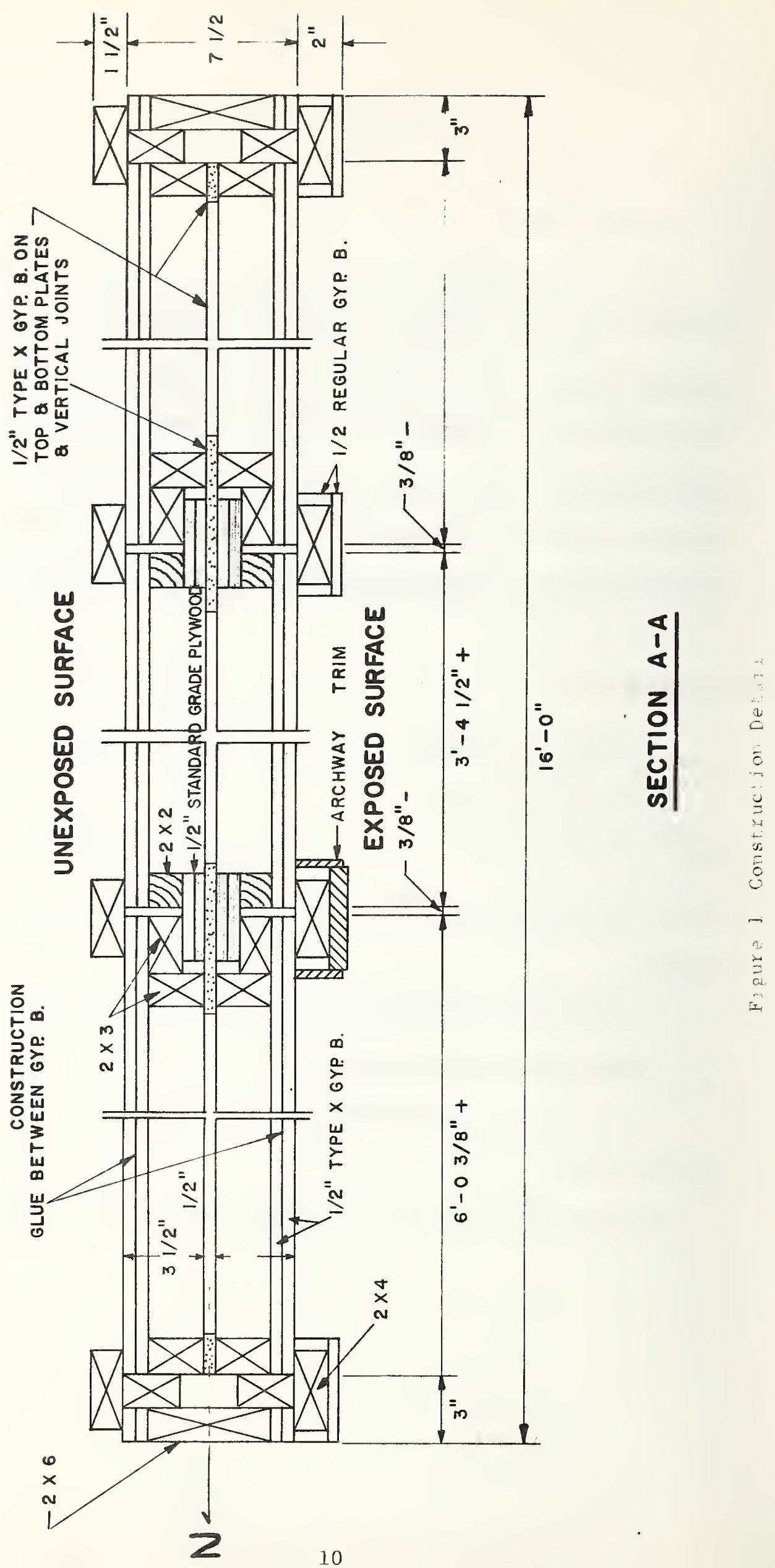




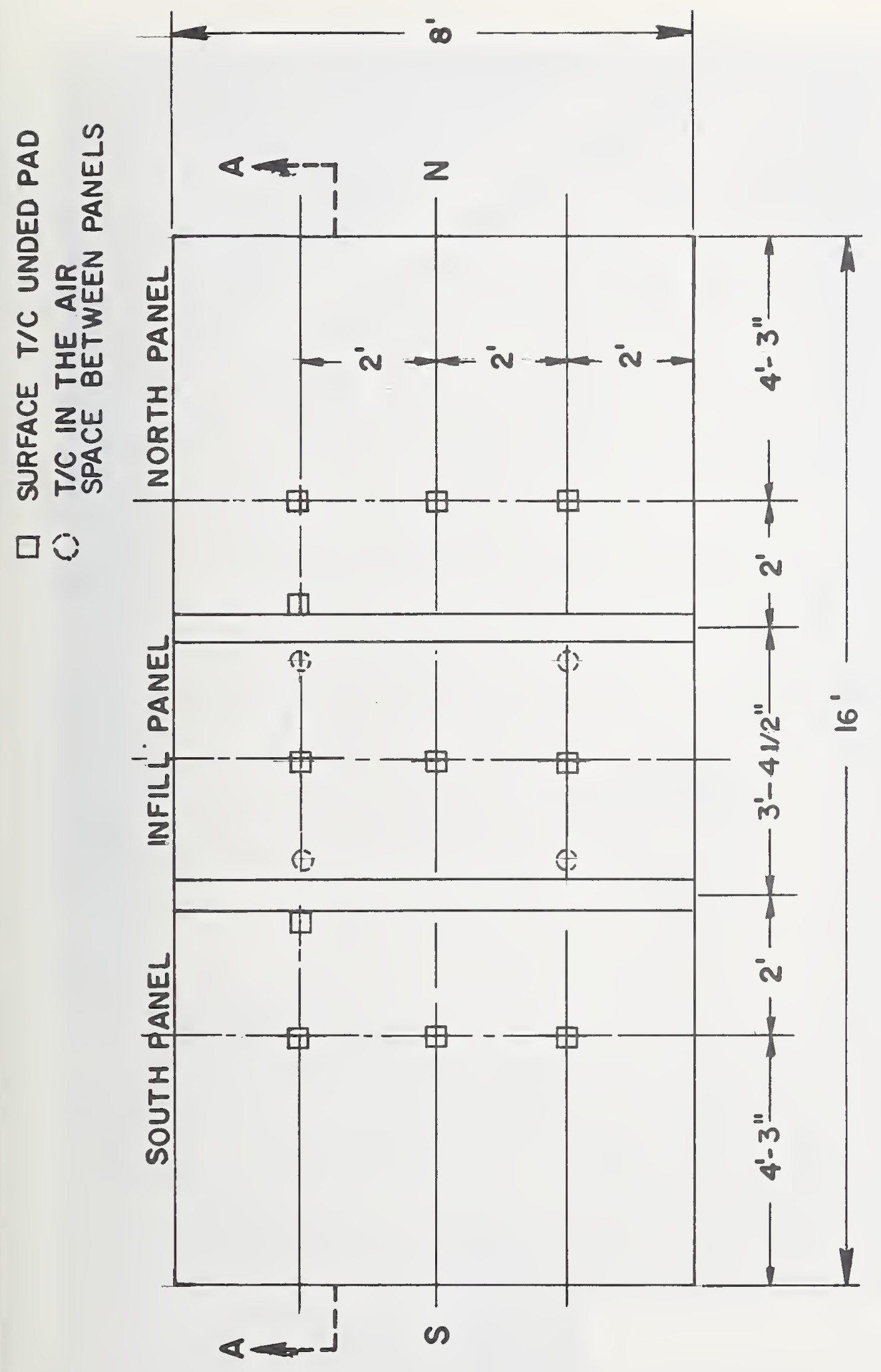

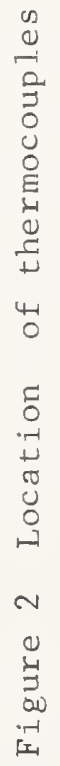




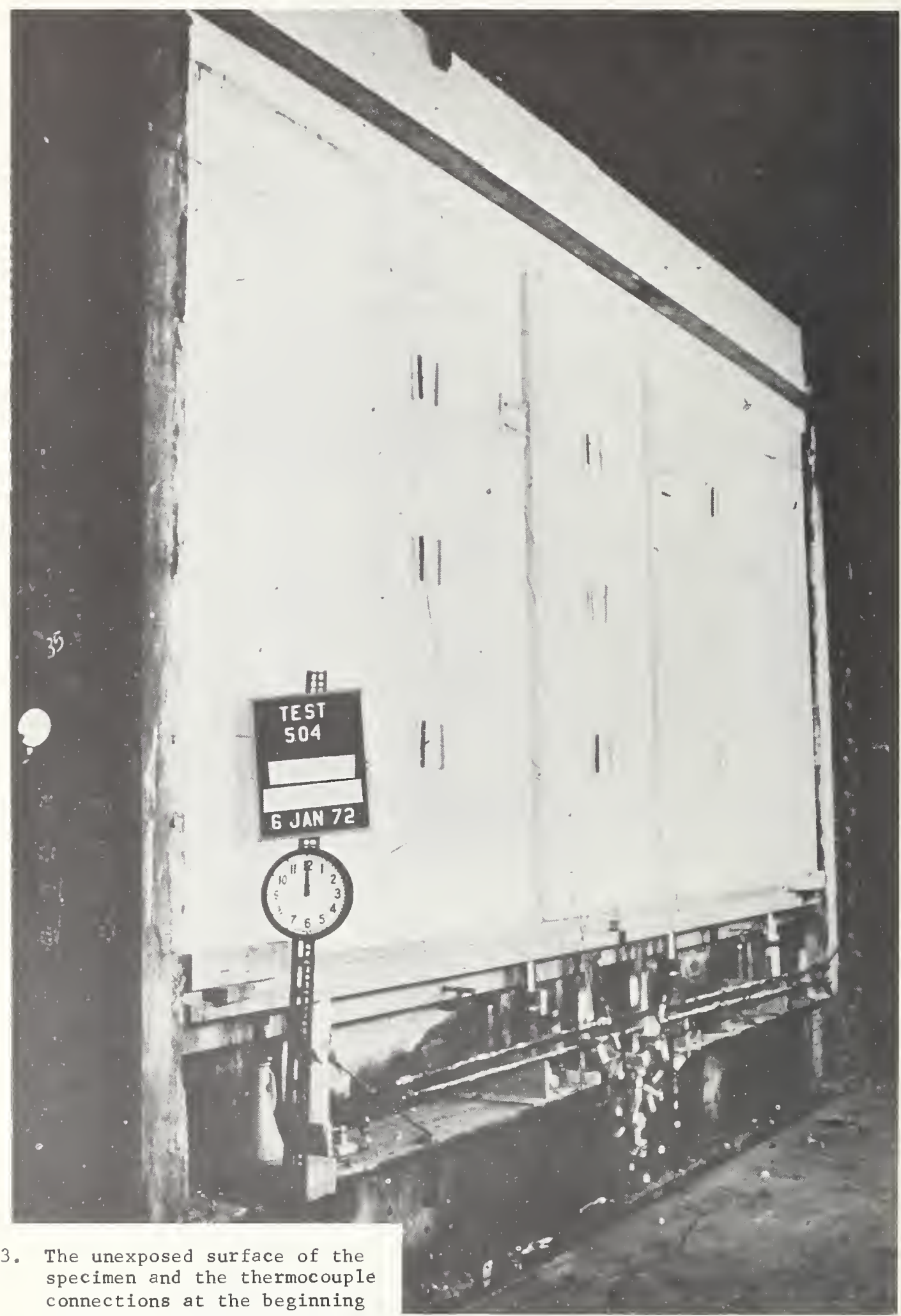

Figure 3. The unexposed surface of the
specimen and the thermocoupl connections at the beginning of the test. Test specimen mounted in furnace. 


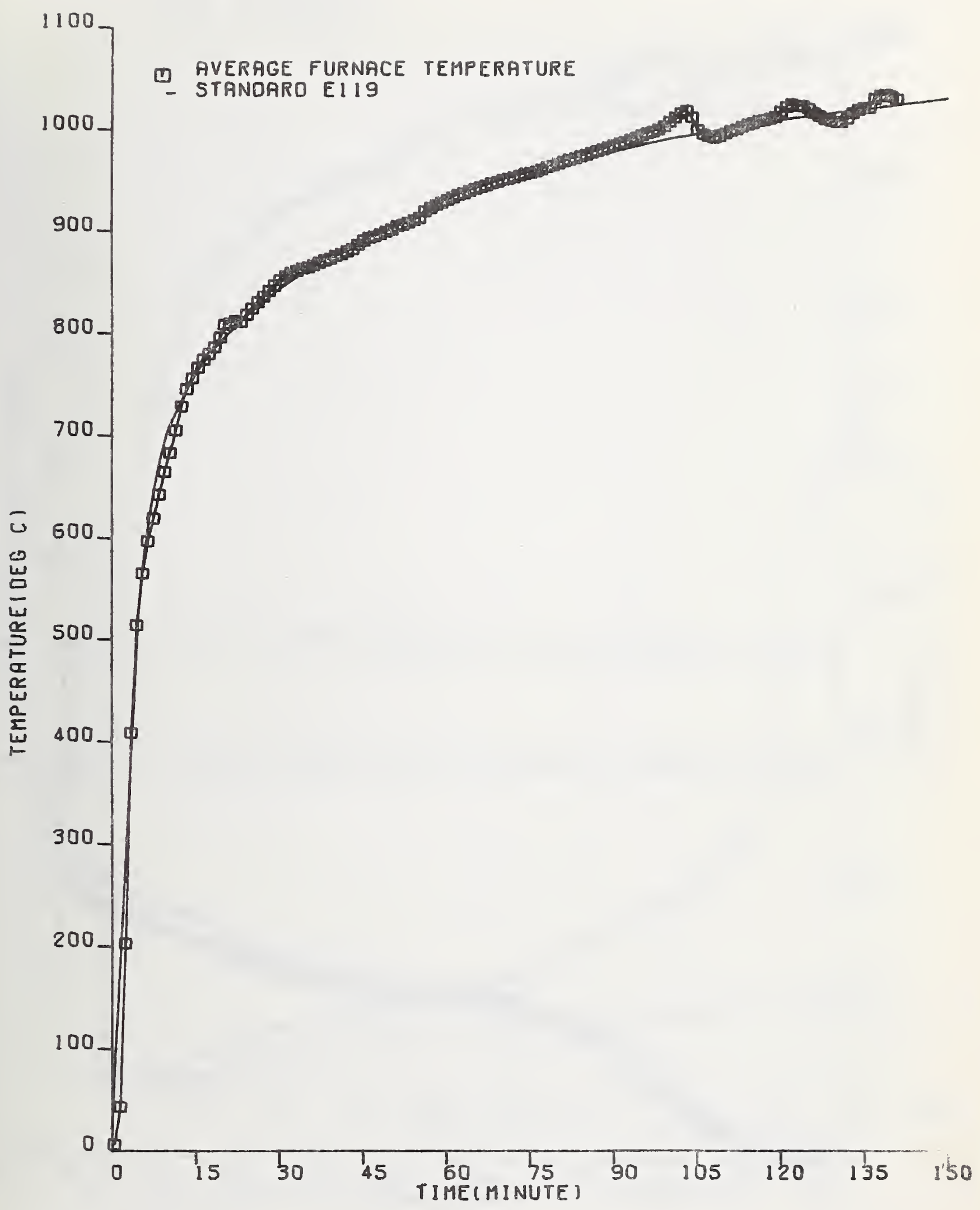

Figure 4 .

AVERAGE FURNACE TEMPERATURE FOR TEST 504 COMPARED WTTH STANDARD E 19 CURVE. 


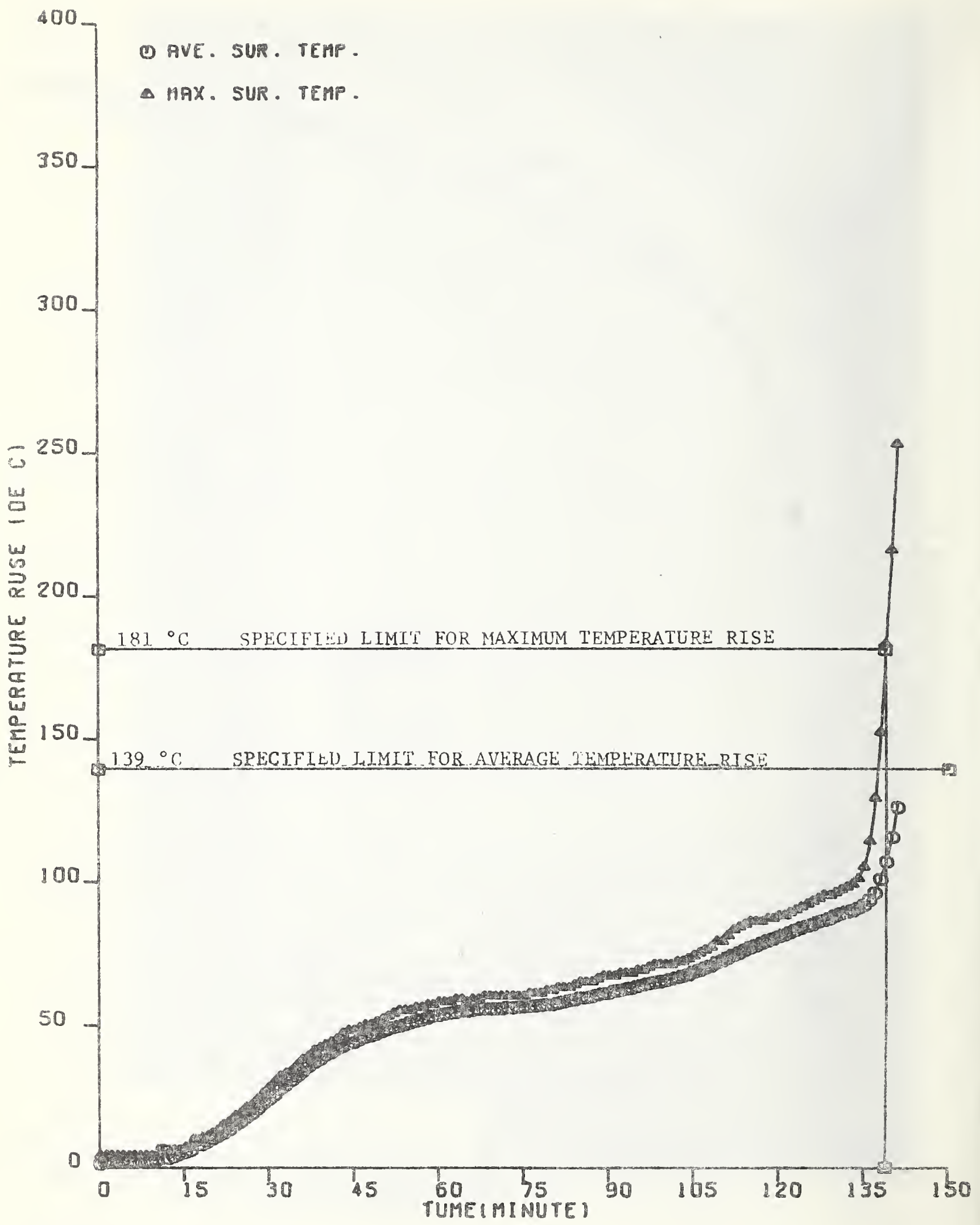

Figure 5 .

MAX, AND AVE。TEMPERATURE RISE ON THE UNEXPOSED SURFACE TEST 504 


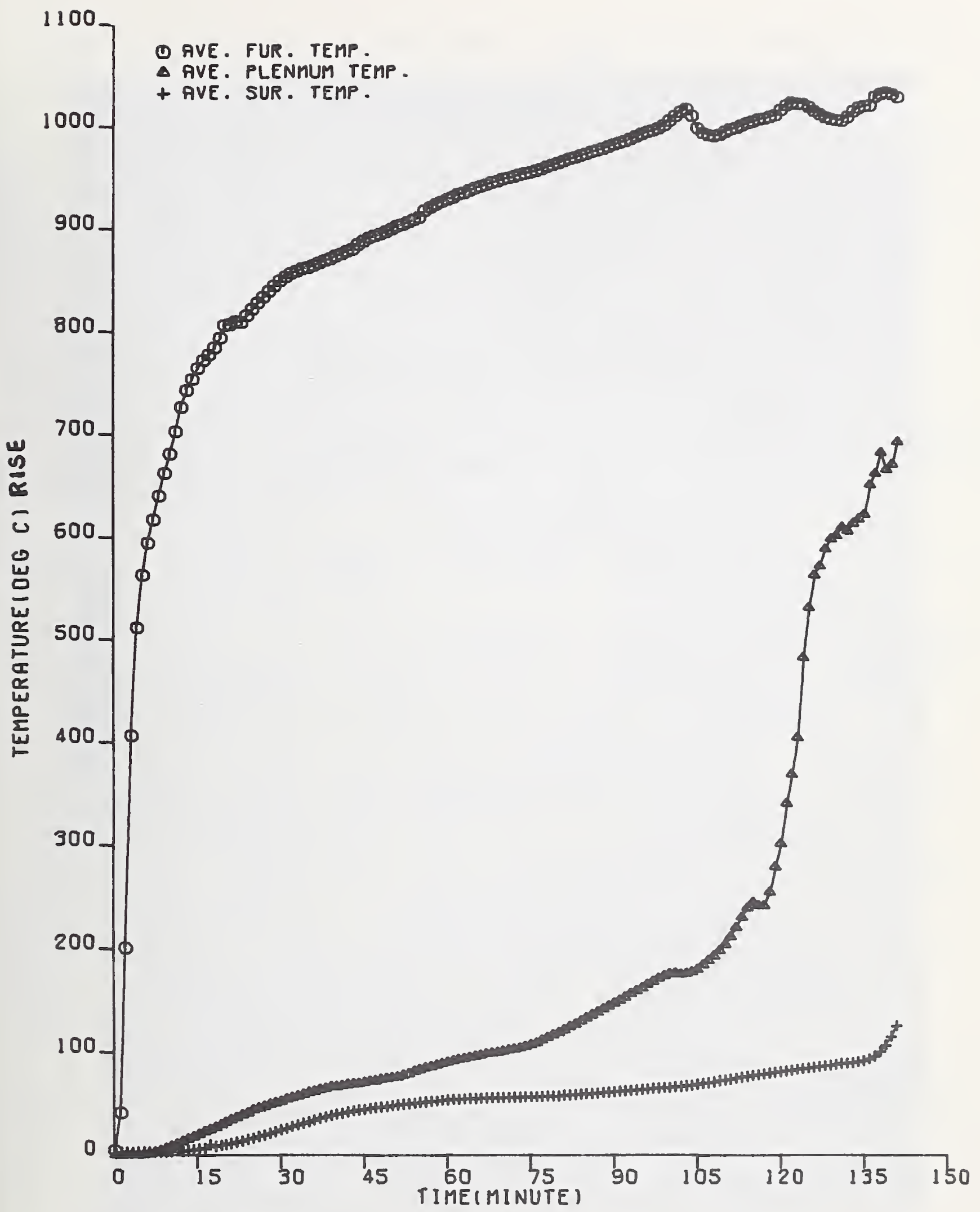

Figure 6.

AVE. AIR SPACE TEMPERATURE COMPARED WITH FURNACE TEMPERATURE AND UNEXPOSED SURFACE TEMPERATURE 


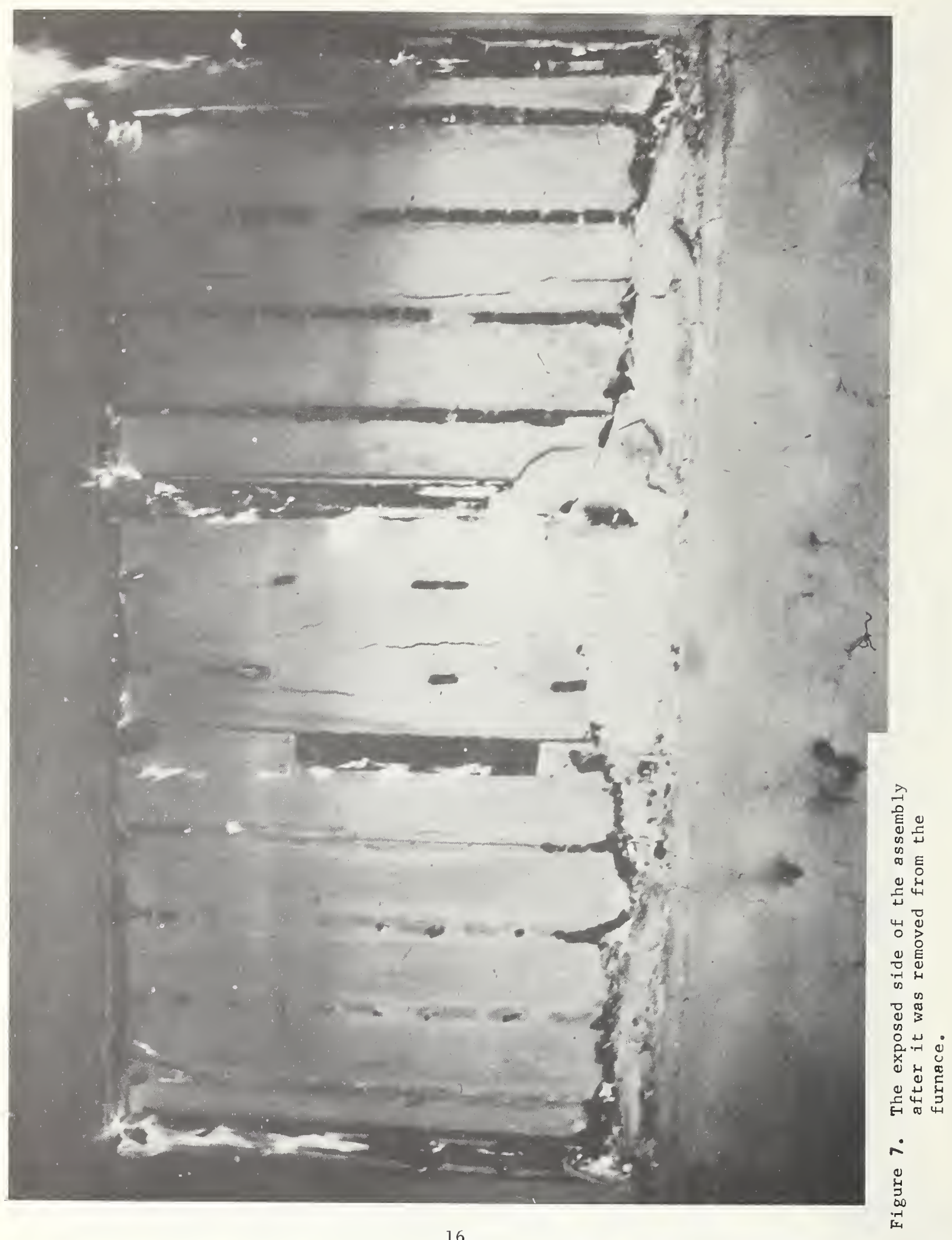


FORM NBS.114A (1.71)

\begin{tabular}{|c|c|c|}
\hline $\begin{array}{l}\text { 1. PUBI.ICATION OR REPORT NO. } \\
\text { NBSTR 73-169 }\end{array}$ & $\begin{array}{l}\text { 2. Gov't Accession } \\
\text { No. }\end{array}$ & 3. Recipient's Accession No. \\
\hline \multicolumn{2}{|l|}{ 4. TITIE AND SUBTITLE } & 5. Publication Date \\
\hline \multicolumn{2}{|c|}{$\begin{array}{l}\text { Fire Endurance Test of a Wood Stud Interdwelling Double } \\
\text { Wall Construction }\end{array}$} & 6. Performing Organization Code \\
\hline \multicolumn{2}{|l|}{ Byung Chan Son } & $\begin{array}{l}\text { 8. Performing Organization } \\
\text { NBSIR 73-169 }\end{array}$ \\
\hline \multirow{2}{*}{\multicolumn{2}{|c|}{$\begin{array}{l}\text { 9. PERF ORMING ORGANIZATION NAME AND ADDRESS } \\
\text { NATIONAL BUREAU OF ST ANDARDS } \\
\text { DEPARTMENT OF COMMERCE } \\
\text { WASHINGTON, D.C. } 20234\end{array}$}} & $\begin{array}{l}\text { 10. Project/Task/Work Unit No. } \\
4600433\end{array}$ \\
\hline & & $\begin{array}{l}\text { 11. Contract/Grant No. } \\
\text { IAA-H-16-70 }\end{array}$ \\
\hline \multirow{2}{*}{\multicolumn{2}{|c|}{$\begin{array}{l}\text { 12. Sponsoring Organization Name and Address } \\
\text { Department of Housing and Urban Development } \\
\text { Washington, D.C. } 20410\end{array}$}} & $\begin{array}{l}\text { 13. Type of Report \& Period } \\
\text { Covered } \\
\text { Fina1 }\end{array}$ \\
\hline & & 14. Sponsoring Agency Code \\
\hline
\end{tabular}

15. SUP PLEMENTARY NOTES

16. ABSTRACT ( $\mathrm{A}$ 200-word or less factual summary of most significant information. If document includes a significant bibliography or literature survey, mention it here.)

As a part of the evaluation of a housing system proposed under Operation BREAKTHROUGH a standard fire endurance test was performed on a double wall construction representIng a non-load-bearing interdwelling wall for single family attached housing. The test was conducted at the National Bureau of Standards and followed the requirements of ASTM E 119, Fire Tests of Building Construction and Materials.

The double wall which represented an interdwelling separation between two adjacent modules, was made up of two identical parallel walls separated by a $1 / 2$ inch air space. Each wall contained two layers of fire-rated gypsum board attached to wood stud framing on the dwelling room side.

Since the test assembly represented a non-bearing wa11, no load was applied during this test.

The failure of the first (fire exposed) wall occurred at 1 hour:17 minutes when a joint in the second layer of gypsum board opened to allow passage of flame.

The second (unexposed) wall failed at $2 \mathrm{hr} .19 \mathrm{~min}$. when the temperature rise at one point on the exposed surface exceeded the maximum allowable.

17. KEY WORDS (Alphabetical order, separated by semicolons) Fire endurance; fire test; flame-through failure of walls; housing systems; interdwelling wall; Operation BREAKTHROUGH

18. AVAILABILITY STATEMENT

[x] UNL IMITED.

FOR OFFICIAL DIST RIBUTION. DO NOT RELEASE TO NTIS.

\begin{tabular}{|c|c|}
\hline $\begin{array}{l}\text { 19. SECURITY CLASS } \\
\text { (THIS REPORT) } \\
\text { UNCL ASSIF IED }\end{array}$ & 21. NO. OF P UES \\
\hline $\begin{array}{l}\text { 20. SECUR ITY CLASS } \\
\text { (THIS PAGE) }\end{array}$ & 22. Price \\
\hline UNCL ASSIFIED & \\
\hline
\end{tabular}


